\title{
191. Fehler und Gefahren bei der Versorgung von Nasen- und Gesichtsweichteilen
}

\author{
C. Walter \\ Klinik am Rosenberg, CH-9410 Heiden
}

\section{Mistakes and Dangers in the Treatment of Injuries to the Soft Tissue of the Nose and Face}

Summary. The aim of each wound closure is to create an equal distribution of the anticipated forces of cutaneous and subcutaneous contraction. Wounds more than $2 \mathrm{~cm}$ in length should be broken up by counter cuts. The excision of wound margins in the face is hardly ever advisable and may even be wrong. There is also a very limited indication for using split thickness skin grafts and the surgeon is ill advised to use such a graft to bridge two different compartments of the face.

Key words: Broken line technique - Flaps.

Zusammenfassung: Das Ziel einer Wundversorgung liegt in der Schaffung von gleichmäßig verteilten Zugkräften an der Haut und im Unterhautbereich. Gefahren drohen, wenn bei Abscherverletzungen der Haut nicht gleichmäßige subcutane Vernarbungsverhältnisse geschaffen werden. Wunden über $2 \mathrm{~cm}$ Länge müssen unterteilt werden. Wenn möglich keine Wundrandexcisionen vornehmen; keine Spalthaut verwenden, schon gar nicht über 2 verschiedene Gesichtseinheiten. Fehlerhaft ist es, Gesichtswunden nicht von innen heraus zu versorgen und offene Stellen in der Nase zu belassen.

Schliisselwörter: Narbenunterteilung - Lappenplastik.

\section{Fehler und Gefahren bei der Erstbehandlung von Augenverletzungen}

\author{
H. Neubauer \\ Universitäts-Augenklinik, Joseph-Stelzmann-Straße 9, D-5000 Köln 41
}

\section{Errors and Risks in the Primary Treatment of Eye Injuries}

Summary. 1. Injuries of the lids and canaliculi: missed reconstruction of the levator or canaliculus etc. 2. Transpalpebral perforations of the globe often escape notice (hematoma of the lids following impalement, severe concussion, perforation by foreign body. 3. Intraocular foreign bodies may be overlooked in the case of transscleral entrance. 4. Lesions of the optic nerve (orbital hemorrhage, fractures, impalements). Primary enucleation is indicated only in the case of extreme laceration up to the posterior pole of the globe.

Key words: Ocular adnexa injury - Perforation wounds of the eye - Orbital fractures - Enucleation.

Zusammenfassung. 1. Verletzung der Lider und Tränenwege: versäumte Rekonstruktion eines abgerissenen Lidhebers, durchtrennter Tränenwege u. a. 2. Transpalpebrale Augapfelverletzungen werden leicht übersehen (Lidhämatom nach Pfählung, schwerer Kontusion, Fremdkörper (FK)-Perforation). 3. Intraoculare FK werden bei transskleralem Einschuß oft nicht erkannt. 4. Orbitale Opticusläsion bei schweren Hämatomen, Orbitaspitzenfraktur, Pfählungen. - Primäre Enucleation heute nur noch nach schwersten Zerschneidungen bis zum hinteren Augenpol.

Schlisselwörter: Verletzungen der Augenadnexe - Perforation des Augapfels - Orbitafraktur - Enucleation. 